\title{
The impact of migration on the leading innovative development of the employment potential
}

\author{
Roman Chornyi \\ Novovolynsk Research Institute of Economics and Management \\ Ternopil National Economic University \\ 11 Lvivska str., 46009, Ternopil \\ Ukraine \\ e-mail: vazyn@i.ua \\ Nelya Chorna \\ Novovolynsk Research Institute of Economics and Management \\ Ternopil National Economic University \\ 11 Lvivska str., 46009, Ternopil \\ Ukraine \\ e-mail: n.chorna@tneu.edu.ua \\ Mariya Lalakulych \\ Uzhgorod Trade and Economic Institute of the Kyiv National Trade and Economic University \\ Korynyanska str. 4, 8020 Uzhhorod \\ Ukraine \\ e-mail: info@utei-knteu.org.ua
}

\begin{abstract}
This paper focuses on the influence of migration on the leading innovative development of the labor potential. Moreover, it considers the main stimulate impacts of migration on innovative development of employment potential and risks of their use. The paper postulates the priority of educational qualification component in ensuring the innovative development of the employment potential is proved that in the future will overcome many challenges in the sphere of social and labor relations. Within this context, the need for using legal migration as the source of abundant and high-quality labor for the labor market should be considered.

The paper develops and shows two scenarios of the development of employment potential of the regions with the destruction and preservation of the institutional environment on the basis of the employment of re-emigration and stimulating of the migration of highly skilled workers to the region.
\end{abstract}

\section{Introduction}

At present, migration processes throughout the world stay under the scrutiny of leading researchers and society. Preferably, the focus on migration processes is concentrated on the negative manifestations in developed countries where migrants in developed countries are a growing threat to the local population and in developing countries due to the outflow of labor force and skilled personnel. Nowadays, migration provides one of the key influences on the formation of labor potential in countries and regions, including Ukraine. In addition, mostly in a negative context because of the very large number of Ukrainian citizens who emigrated from the country or stay in other countries as "migrant workers". At the same time understandable is the fact that the impact of migration processes on the formation of labor potential is multifaceted (Stojanov et al. 2011).

Many scholars identify the innovative development of labor potential as the process of separation in its component structure of innovative component (Pasyeka 2013; Chvátalová 2016; Ushakov et al. 2017; NiñoAmézquita et al. 2017; or Al-Kahtani 2018). Often it is possible situation that in certain regions are concentrated large volumes of non-initiated labor capacity due to the low capacity of the labor market and a glut of positions for certain professional qualification requirements, while at the same time in another feel shortage of labor potential (Volchik et al. 2018). Therefore, in another aspect the innovative development of labor potential is also determined as engine of forming the regional innovation systems based on efficient use of human skills and ideas (Hryshchenko and Kovalenko 2011; Mishra and Singhania 2014; Čábelková et al. 2015; or Danshina and Britchenko 2017).

Regarding the development of employment potential of Ukraine determinations by migration has always remained problematic (see e.g. Malynovska 2007; or Tolstokorova 2009). In this regard, practically every study of various aspects of the labor potential in the domestic science affect in some extent on the migration issue. Often is the dilemma of enormous demographic losses of the country, which cannot accurately be determined in a quantitative sense (Britchenko et al. 2018). For the different types of settlements impact the migration factor 
appears with different force - for small towns and rural localities is characterized by much higher territorial mobility than for residents of large cities, where relatively better living conditions and opportunities of employment (Strielkowski and Rausser 2013; or Strielkowski et al. 2015). Thus, migration traditionally perceived by scientists and the public in a negative sense. However, in terms of the complexity of solving the many problems in the sphere of industrial relations should seek ways of transforming the destructive effects of various phenomena and processes in constructive, thus providing opportunities for the development of labor potential of the population, including the innovative principles.

\section{Theoretical and methodological aspects}

Meanwhile, the stimulating nature of migration for the development of labor potential takes place and is partly grounded in the theoretical and methodological aspect. However, in practice in the system of management of migration processes of use of incentives determination by migration is very limited (Strielkowski and Weyskrabova 2014; or Strielkowski et al. 2016). To a large extent this is due to lack of clearly developed conceptual guidelines of the state migration policy, weak regionalization of its implementation when the region of the country has its own migration specifics because of its geopolitical location, vectors of migration, migration networks formed over the years, frequent changes of central state authority in the sphere of migration and more.

One can easily define a list of positive effects that can be obtained for domestic labor markets in stimulating of innovation development of labor potential through migration factor (Kunitsyna et al. 2018). It should clearly distinguish between vector nature of migration - internal and external, immigration and emigration, because each of them differently determines employment potential development opportunities for the regions of Ukraine.

Positive heredity of impacts of migrations on the innovative development of employment potential can be roughly distinguish by the groups of its influence. First of all, is the impact on labor markets, among which can be identified:

- In quantitative terms, i.e. lowering the pressure on working places, meeting the need in workers with appropriate skills, including few prestigious professions (that is often characteristic for Ukrainian workers by external vector of migration);

- In qualitative terms, i.e. formation of the motivational environment for the development of potential performance for employees in terms of increasing the labor supply in the market.

Among the positive influences on personality development are basic:

- In the professional field, i.e. acquisition by employee experience, relevant educational qualification characteristics, skills of information technology use;

- In the field of vital activity, in particular changing of ideological foundations on real living standards level in spatial formations-recipients, increasing on this basis of public activity (including through participation in various forms of self-organization of local communities, electoral processes to local governments).

One can also define a positive impact on such processes as:

- Socio-economic development of the territory-donor by investing of migration capital, the acquired by person in the labor activity in another locality, especially overseas (migration capital is not only earned money and other material values, but human capital in the expression through knowledge, skills);

- On the environmental parameters of the vital activity of population through the experience and capabilities of improving home improvement, other objects of social infrastructure and investing in their development (especially attractive here is trade).

None of these positive effects can not be implemented in a strategic perspective for the conditions of unsettled migration flows. That is their clear regulation is mandatory condition of assess the situation and their forecasting to prevent the deepening of the negative consequences of migratory movements of population that largely characterized by progressive character.

Recently, there is a lot of debates on the need to reduce migration losses of Ukraine's population, which strongly reflected in terms of demographic reproduction while increase immigration inflows of citizens of Asian countries that hardly assimilate what is a typical problem for developed countries as well. However, the capacity of regional labor markets and their current inability to "take" millions of Ukrainian workers should be assessed realistically. Therefore, firstly the positive heredity of migration is manifested in reducing of unemployment degree. In ideal conditions migration is a secondary process regarding reaction of population on the socio-economic conditions of residence and work. It allows to balance on quantitative and qualitative characteristics the economically active population according to the needs of regional labor markets. However, under conditions of deep space differences in the level of socio-economic development of different forms of social organization, especially villages and large cities, 
talk about the redistributive function of migration is extremely difficult.

The positive effects of migration impacts are shown as relative of development of different potential components. Priority in the ensuring of innovative development of labor potential of educational qualification components and thus assesses the impact on its migration and does not reject the need of detection such heredity and relative to other potential characteristics, qualities and possibilities of the population. This is especially true the impact on the psycho-physiological component because of the obvious determinations of indicators of demographic reproduction and also the practice of limited social protection of migrants in conditions of illegal and semi-legal migration with gross violation of regulations of labor law and also the determinations of socioeconomic characteristics. Unfortunately, now they appear to be very negative for the Ukrainian economy because they lead to deformations of the social structure of the population with the deepening of the gap in terms of incomes from remittances of migrant workers.

\section{Developing migration scenarios}

Most of the positive effects of migration for the donor territory are possible under conditions of reemigration processes. That is in addition to the need of full regulation and legality of migration, should be promoted the establishment of so-called circulating migration processes. It is possible the two main schemes of circulations (Figure 1).

\section{Scenario 1}

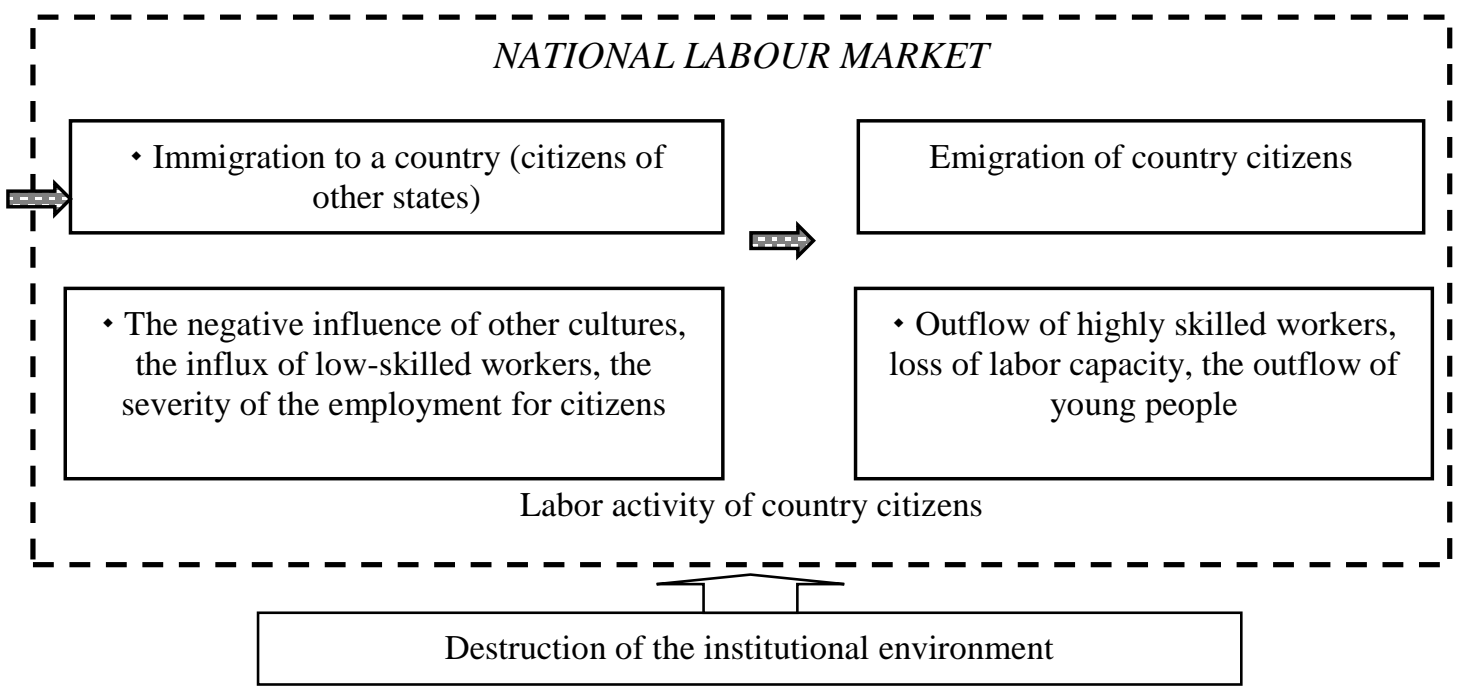

Scenario 2

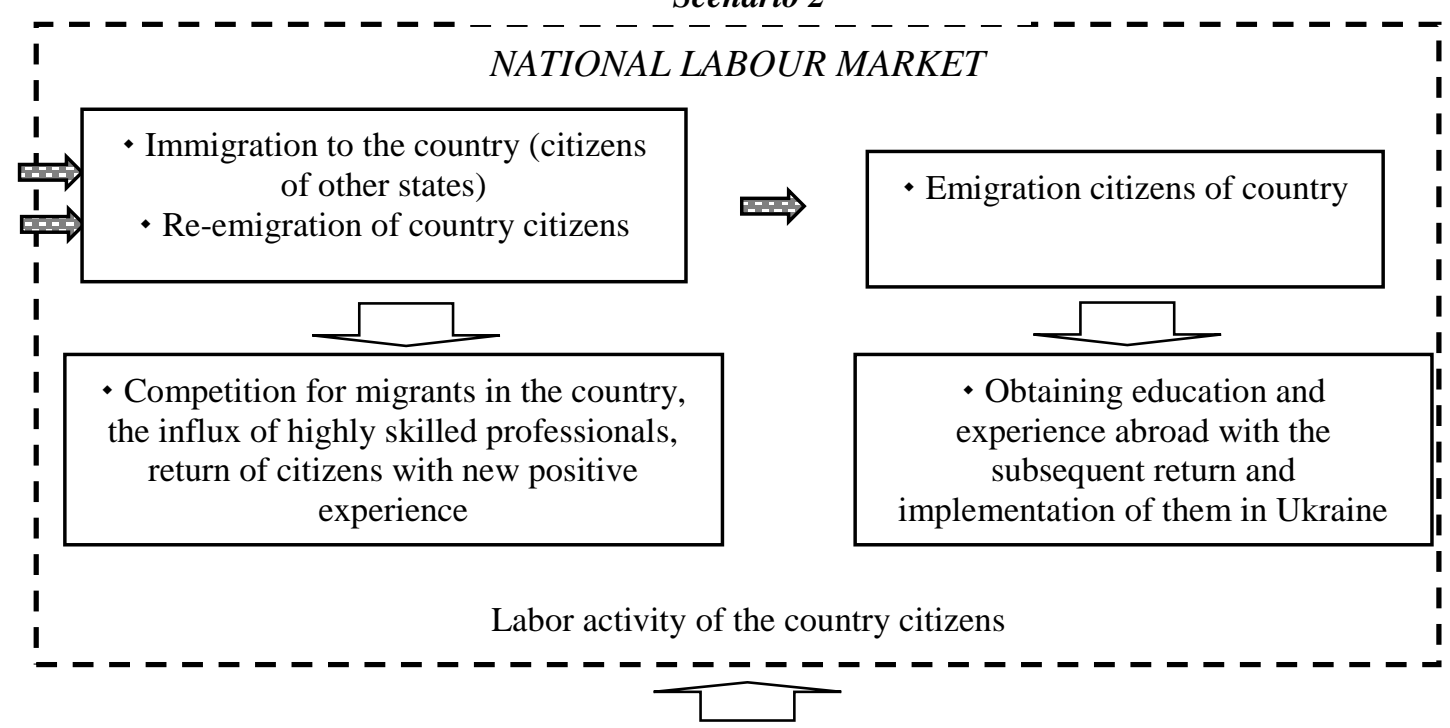

Saving of institutional environment

Fig. 1. Two scenarios of migration circulation (migration and the labor market) Source: Own results 
When circulating migration provides "compensation" of loss of population which means that emigrants are lost via sufficient immigration processes. Of course, it exacerbates segregation problem, social tension and, most importantly, assimilation processes regarding the titular nation. Another aspect is the prevention of destruction of the institutional environment of the country and regions (norms, customs, rules, laws, etc.) due to compensation of emigration loss only partially of immigration, and in its main part - by the re-emigration of citizens of the country with the acquired migration capital. This scenario is important for Ukraine with aim of no repetition of the experience of developed countries. A striking example here might be Paris in the population which according to official figures, about $15 \%$ are foreigners. In reality, their number is much higher, resulting of it is frequent defending the rights of ethnic minorities, the restrictions of which forced the French government because of the so-called "French crisis of national identity". Obviously, these processes for labor markets and labor potential development are not the best, because eventually form a discriminatory environment for citizens with permanent residence (indigenous people) with forced competition with migrants and perception of their culture, values norms and customs that clearly manifest in everyday life.

Ensuring of second scenario of migrations circulation by external vector is actualized for spatial forms of Ukrainian society construction and under conditions of the prospects of joining the European Union (EU), when in fact, form a new plane of reallocation of workforce with forming of powerful centers of attraction of people with the highest employment potential and deepening of periphery state for least developed territories.

Explain the positive effects of migration impact on the development of separate components of labor potential. For the donor territory in terms of development of socio-economic component is specified homogenization of local community, which is a process of elimination of heterogeneity in society (Kravtsiv and Sadova 2009). The truth is quite a fine line of determinations of migration incomes on homogenization and differentiation of society. Currently, the incomes of migrants support the demand for cost goods and services at quite a high level, causing higher prices. On the other hand, they can provide an adequate material level to persons who have relevant potential characteristics. Therefore, under conditions of the absence of migration capabilities gap in terms of population incomes in Ukraine would be felt even more.

\section{Impacts of migration on labor market}

It is important to understand that migration primarily caused positive impact on the educational qualification component namely ensures improvement of professional qualification abilities and skills of the employee. In the system of providing innovative development of employment potential it will give powerful catalyzing effect against the development of other components because of the high level of integration of educational qualification characteristics, qualities and opportunities for work carriers against them. Another important aspect of ensuring the stimulating influence from migration on innovative development of employment potential is its legal status. Only on the legal basis of migrant labor activity is in the legal framework of the country of employment and regularities of international law. Under other conditions opportunities of employment potential development there almost always are absent. Instead, the practice of excessive exploitation of potential characteristics, qualities and opportunities for work carriers, which further reflected in their re-intellectualization, full or partial loss of their employability is often present.

Especially important is stimulation of the positive impact from migration processes on educational qualification component of the employment potential of developing countries in the light of the rapid development of automation and artificial intelligence that significantly change the social and labor relations and human progress (Shevchuk 2016a; 2016b). Educational institutions without implementation environment of relevant informational technologies should act also as active agents of their production and development. However, according to official statistics data, in the overall structure of companies and organizations that have used high technologies, educational institutions share is only 3.7\% (59.6\% - industrial companies, $17.4 \%$ organizations that engaged in real estate activities, leasing, engineering and services, $10.3 \%$ - enterprises of transport and communications) (State Statistics Service of Ukraine 2016). Obviously, this figure proves practical influence on the educational sphere on innovation processes in the regions, and thus the production of ideas and the spread of new informational technologies.

Realizing of universality of the stimulating effects of migration on the innovative development of employment potential, consider the territorial specificity of such influence. Destructiveness of migration for different spatial forms increases depending on the depth of the gap in the level of socio-economic development between the donor settlement and recipient settlement (depth as quantitative gap by the relevant parameters and time of their appearance and increasing). The perception of the value of such gap by individual migrant is made with the assessment of opportunities:

- Employment and mobility on the local labor market, i.e. the ability of finding of better working with conditions that corresponding acquired educational qualification level and experience (if is present);

- Comfortable housing improvement with quality and accessible municipal services; 
- Consumption of quality services of social infrastructure entities;

- Development - education, leisure (own and own family members);

- Recreation - healthy eating, stay in ecologically clean environment (although in the value system of workers from Ukraine this option of estimation is not as important);

- Establishment of friendly mutual relations in the near and distant social environment.

Seeing regularity of strengthening of migration processes in spatial forms with significantly worse opportunities of employment and environmental living conditions, and also the difficulty of obtaining positive effects from them under conditions of remarkable depth of the gap in the level of socio-economic development of the donor territory and recipient territory, firstly appears the task of finding of ways of solutions of migration issue for rural areas.

The variability of migration for rural settlements involves their activation by an internal vector (within the region or to other regions on the scheme "village-city"), and also with clear migration settings on travel abroad. According the obtaining of stimulating effects from migration for this type of settlement is a very difficult task. Currently, more relevant question is partial regularity of migrations from the countryside. This can be achieved by finding new ways to improve economic conditions here with the creation of work opportunities for peasants.

Domestic realities show that the complexity of employment in rural areas with subsequent forced migration occurs not only in rural areas but also in small and medium-sized cities, including those that are regional centers regarding these villages. So now solving the problem of employment opportunities in rural settlements should be carried out not only on their level, but also at the level of district centers as local centers of business activity. Thus, residents of rural settlements through the shuttle (preferably daily) migratory movements will be able to carry out its labor activity in the close cities, while not forming in it the phenomenon of distant family with prolonged heredity of emergence of so-called migrant families in many generations (when parents experience on work activity abroad transmitted to their children, who after graduation also looking for better opportunities of life in not the place of residence). Then the pendulum migrations will partially displace susceptibility to external migration movements, with all their accompanying risks and problems.

One of the main objectives is also establishing a general framework for problematic use and development of the employment potential of rural residents and priority ways of gradual reduction through alternative migration and stimulating of re-emigration processes that actually will allow to get the most important incentives for the development of the employment potential from this controversial process to rural areas. Paradoxically, but the transformation of the migratory impacts in stimulating to the development of the employment potential for the Ukrainian village is perhaps more necessary than for other types of settlements. For situation of practical lack of opportunities of employment potential development, especially on the innovative principles the ensuring of gradual economic revival in rural settlements can begin from the migration factor profitability through reemigration processes and investing of migration capital into the local economy.

Typically, a person as potential migrant is not focused on remote migration, that is, one that requires overcoming significant distances and prevents frequent (weekly or at least once a month) visit the place of previous residence. Firstly, it evaluates the possibilities of work in geographically close spatial formations, particularly within the area of residence or neighboring (more developed in socio-economic terms, such as Lviv for Volyn) region. This assessment passes not only with an eye on the possibility of labor as such, but also to obtain as a result of corresponding benefits:

1) material, i.e. worthy wages, monetized social benefits;

2) moral, i.e. obtaining of satisfaction from the results of their work, opportunities for self-fulfillment and development, including with the display of propensity to innovation activity;

3) social namely full social and psychological adaptation in the labor group, establishment and expansion of social contacts, friendly relationships between colleagues and administration.

Generally, the higher the employment potential of person, potential migrant and their propensity to innovative activity, the higher the demands on working conditions. Hence the lack of their satisfaction leads to migration movements in those labor markets where the competitive environment hereditarily manifested in offers the best opportunities for employment.

In return for villages justification of the need for identifying and solving the problems of the labor potential development arises because of a long decline of the Ukrainian village that repeatedly justified by domestic scientists (Honcharenko 2009). In fact, there are long-term processes of deterioration of the welfare of the peasants due to depreciation of human labor, non-compliance with labor laws, reducing of employment and possibilities to obtain the necessary goods and services, which can be a likely cause of the degradation of human capital and rural economic space in general (Skyba 2012).

For residents of the village that acquired sufficient level of labor potential and which is characterized by objective requirements for working conditions, difficult socio-economic conditions in his native settlement somehow determine growth of territorial mobility. Further positive experience of remote (abroad or in another region, including the capital, with much better work conditions) migration of other persons often leads to the 
transformation of the high mobility of person in the actual migration. The prevention (actual overcoming) mass of such processes in Ukrainian village should be done through:

- Change of vectors of migrations from external and inter-regional to internal pendulum;

- Re-emigration of labor migrants by selective approach (through targeted programs) with an eye on investment their migration capital in agricultural cooperatives and other attractive from them forms to business.

The change of vectors of migrations from external to intra-regional pendulum with orientation, as already mentioned above, on the revitalization of business activities in district centers is a suitable variant for those settlements, where saved a certain infrastructure economic base from previous years. Restoration of enterprises of the Soviet period now seems hopeless. However, those objects that were in functioning in the years of independence Ukraine could be partially restored with their transfer into the concession to investors on a competitive basis or on other mutually beneficial conditions.

The problem of business development in the settlements that are marked depression, and therefore further opportunities to use and develop the employment potential of the population, largely lies in the political sphere with the subjective approach to its support. Partly to overcome this destructive allows practice the creation of specific spatial forms of social organization. However, the effectiveness of their functioning requires retrospective evaluation in order to avoid previous mistakes and use the most thoughtful approach for stimulating of business activity. It is important to consciously restrict the territorial coverage of special economic conditions of economic activities and degrade the institutional level of their organization. For example, the same practice of priority development territories that had justified itself in a strategic perspective, proves the need to intensify business with target orientation on specific areas of economic activities.

Thus, migration can be a stimulus for innovation development of labor potential in case of its legality, adjustment and ensuring its circulation while preserving national institutional environment through re-emigration processes. Significant social and economic effects can be achieved through investment of migration capital into the local economy. Overall impact forms of migration capital on innovative development of labor potential in the region (settlement of previous residence place) is very diverse and individualized and can be represented in generalized form as:

- Entrepreneurial activity;

- Straight through beginning of own business;

- Indirectly through the transfer of the correspondent amount of funds to family members or other trusted individuals to start business or develop existing business;

- Indirectly through various forms of investment, including the purchase of securities;

- Labor activities through hiring in the respective management or other positions with the ability to use the acquired knowledge and experience and worthy their payment in the stimulation system;

- Public and social activity on voluntary foundations with the ability to use the acquired knowledge and experience in improving of living standards of population, living improvement, improving the legal culture of local communities, etc.;

- Socialization with the dissemination of information on working conditions, lifestyles, public forms of influence on government and public institutions, rights protection mechanisms, etc. in other spatial entities (especially in foreign countries) among close and distant social environment.

One should pay attention to the latest form of influence of migration capital as acquired knowledge, experience and wealth of migrant during the period of employment in another locality. In fact, such person turns into extremely important source of information. By his own experience former migrant may motivate other members of the society who come to him in occasional social contacts, to migration, or vice versa objectively assess the benefits of living in his native land. Besides such person as a carrier of information about the conditions of work and life in other spatial entities, including foreign countries, forms through their social contacts of close persons specific information field, which is the transfer of relevant information with the ability to refine it if necessary. Therefore, for one group of people the obtaining of information about the possibilities of better working conditions and living in remote settlements can serve as a temporary motivator for obtaining the required educational qualification degree with followed emigration. Thus, the state investment in human capital can be ineffective.

\section{Conclusions}

Therefore, migration should not be generalized only to negative heredity by influence on the development of labor potential. It can serve as a powerful catalyst for innovation development through involving the migration 
capital in the local economy. Currently the national job market under conditions of acute work redundancy and deepening of systemic crisis is not prepared to provide an opportunity for employment of Ukrainian workers. But he desperately needs investment resources, which under conditions of the competent migration and financial credit policy can be obtained with the infusion of funds earned abroad with opportunities of the next reemigration. Seeing priority of educational qualification component in ensuring the innovative development of the employment potential that in the future will allow overcome many challenges in the sphere of industrial relations, is important to fight with illegal migration displays, resulting in a gross violation of labor law regularities. In such circumstances the possibilities of labor potential development for migrants is lost. Instead, there is a significant threat to potential characteristics because of practice of excessive physical and psychoemotional stresses, irregular working hours, lack of decent (satisfactory) conditions of living, recreation and food. If the migration has legal status, then almost always it is invaluable work experience and re-emigration of such persons at home should be brought strategic task of modern government in terms of target employment and stimulating of their entrepreneurship.

\section{References}

Al-Kahtani NS (2018) Perception of private telecom employees towards unfair HRM practices: an empirical investigation. Entrepreneurship and Sustainability Issues 5(4):957-966. doi: 10.9770/jesi.2018.5.4(18)

Britchenko I, Polishchuk Y, Ivashchenko A (2018) Implementation of ICO European best practices by SMEs. Economic Annals-XXI 169(1-2):67-71. doi: 10.21003/ea.V169-13

Č́belková I, Abrhám J, Strielkowski W (2015) Factors influencing job satisfaction in post-transition economies: the case of the Czech Republic. International Journal of Occupational Safety and Ergonomics 21(4):448-456. doi: 10.1080/10803548.2015.1073007

Chvátalová I (2016) Social policy in the European Union. Czech Journal of Social Sciences, Business and Economics 5(1):37-41. doi: 10.24984/cjssbe.2016.5.1.4

Danshina Y, Britchenko I (2017) Adaptation of domestic state governance to international governance models. Baltic Journal of Economic Studies 3(5):116-124. doi: 10.30525/2256-0742/2017-3-5-116-124

Honcharenko IV (2009) Sotsial'no-ekonomichnyy rozvytok sil's'kykh terytoriy rehionu: problemy teoriyi ta praktyky [Socio-economic development of rural areas of the region: problems of theory and practice], Lviv: Institute of Regional Research of the NAS of Ukraine, $120 \mathrm{p}$.

Hryshchenko VF, Kovalenko LY (2011) Ekonomichna otsinka trudovoho potentsialu terytoriyi z urakhuvannyam ekolohichnoho faktora $\mathrm{v}$ konteksti innovatsiynoho rozvytku [Economic evaluation of the employment potential of the territory taking in attention environmental factor in the context of innovative development]. Marketing and Management of Innovations 2:231-237.

Kravtsiv VS, Sadova UY (eds.) (2009) Mihratsiyni yavyshcha ta protsesy: ponyattya, metody, fakty [Migration Phenomena and Processes: Concepts, Methods, Facts] (Handbook). Lviv: Institute of Regional Research of the NAS of Ukraine, $220 \mathrm{p}$.

Kunitsyna N, Britchenko I, Kunitsyn I (2018) Reputational risks, value of losses and financial sustainability of commercial banks. Entrepreneurship and Sustainability Issues 5(4):943-955. doi: 10.9770/jesi.2018.5.4(17)

Malynovska O (2007) Migration in Ukraine: challenge or chance? European View 5(1):71-28

Mishra US, Singhania D (2014) Contrasting the Levels of Poverty against the Burden of Poverty: An Indian Case. International Economics Letters 3(2):26-35.doi: 10.24984/iel.2014.3.2.1

Niño-Amézquita J, Dubrovsky V, Jankurová A (2017) Innovations and competitiveness in regional development: a comparison of Latin America, Europe, and China. Czech Journal of Social Sciences, Business and Economics 6(1):28-36. doi: 10.24984/cjssbe.2017.6.1.4

Pasyeka SR (2013) Rozvytok sotsial'no-trudovoho potentsialu v umovakh modernizatsiyi ekonomiky rehionu [Development of social and employment potential under conditions of the modernization of the regional economy], Thesis defended for a degree of Doctor of Sciences in Economics, Simferopol, Ukraine).

Shevchuk AV (2016a) Artificial intelligence and intellectualization: New prospects for economic development. Naukovyy ohlyad [Scientific Review] 4(25):27-36. 
Shevchuk AV (2016b) Rozvytok rynku shtuchnoho intelektu: hlobal'ni ta natsional'ni perspektyvy i ryzyky [Market development of artificial intelligence: global and national perspectives and risks]. Visnyk Odes'koho natsional'noho universytetu. Seriya: Ekonomika [Odessa National University Herald. Series: Economics] 21(2):13-17

Skyba TV (2012) Determinanty rozvytku sil's'koho pidpryyemnytstva [Determinants of rural entrepreneurship development]. Regional Economy 2:55-63.

State Statistics Service of Ukraine (2016) Stvorennya i vykorystannya vysokykh tekhnolohiy ta ob"yektiv prava intelektual'noyi vlasnosti na pidpryyemstvakh Ukrayiny [Creating and using high technology and intellectual property rights in the Ukraine], Statistical information. http://www.ukrstat.gov.ua Accessed 20 Aug 2018

Stojanov R, Strielkowski W, Drbohlav D (2011) Labour migration and remittances: current trends in times of economic recession. Geografie 116(4):375-400.

Strielkowski W, Hlustikova, K, Malynovska O, Horvathova Z (2015) Ukrainian migration in the EU: a comparative analysis of migration and remittence behaviour. Geografie 120(3):372-396.

Strielkowski W, Weyskrabova B (2014) Ukrainian Labour Migration and Remittances in the Czech Republic. Tijdschrift voor economische en sociale geografie 105(1):30-45. doi: 10.1111/tesg.12052

Strielkowski W, Rausser G (2013) International Labour Migration and Structural Channels: A Case Study of Ukrainian Working Migrants in the Czech Republic. Ekonomicky Casopis 61(10):1034-1052.

Strielkowski W, Tumanyan Y, Kalyugina S (2016) Labour Market Inclusion of International Protection Applicants and Beneficiaries. Economics \& Sociology 9(2):293-302. doi: 10.14254/2071-789X.2016/9-2/20

Tolstokorova A (2009) Who cares for carers?: Feminization of labor migration from Ukraine and its impact on social welfare. International Issues \& Slovak Foreign Policy Affairs 18(1):62-84

Ushakov D, Bandurina N, Shkodinsky S (2017) Country's Welfare as an Efficiency Factor in Fiscal Policy Promoting Economic Growth. Montenegrin Journal of Economics 13(2):121-127. doi: 10.14254/1800$5845 / 2017.13-2.7$

Van Mol C, Snel E, Hemmerechts K, Timmerman C (2018) Migration aspirations and migration cultures: A case study of Ukrainian migration towards the European Union. Population, space and place 24(5):e2131. doi: $10.1002 /$ psp. 2131

Volchik V, Klimenko 1, Posukhova O (2018) Socio-economic sustainable development and the precariat: a case study of three Russian cities. Entrepreneurship and Sustainability Issues 6(1):411-428. doi: 10.9770/jesi.2018.6.1(25) 